\title{
Study on the Undergraduate Specialty Construction of Human Geography and Urban- Rural Planning Major in Colleges and Universities
}

\author{
Yu-Fen WANG ${ }^{1, a}$, Jin-Xian HAN ${ }^{1, b}$ and Shu-Fang SANG ${ }^{1, c}$ \\ ${ }^{1}$ School of Environmental Economics, Shanxi University of Finance and Economics, Taiyuan, \\ Shanxi, China \\ a'sxwyflzy@126.com, ${ }^{\text {b }}$ hanjinxian2009@163.com, ${ }^{c}$ 1650807618@qq.com
}

Key words: Colleges and universities, Specialty construction, Human geography and urban -rural planning.

\begin{abstract}
Human geography and urban-rural planning major, as the new undergraduate specialty set up in 2012, is still in the exploration. This article mainly analyzed the construction of Human geography and urban-rural planning from professional orientation and curriculum system. This paper also summarized and combed the relevant theoretical and practical achievements and provided reference for the development and construction of the specialty.
\end{abstract}

\section{Introduction}

Human geography and urban-rural planning is the newly established undergraduate major of geography in the undergraduate major catalogue of general colleges and universities of the ministry of education in 2012. Its predecessor was the major of resource environment and urban-rural planning management established in 1998. The major of resource environment and urban-rural planning management is the newly-added geography subject of the ministry of education in 1998, and first enrolled new students in 1999. By 2009, the number of colleges and universities (including independent colleges and private colleges) has reached 173, becoming one of the fastest new majors in China. Due to the major related to science, engineering and management, there are many universities in China set up the undergraduate major, including comprehensive universities, normal universities, engineering colleges, geological and mineral universities and other colleges.

The major of resource environment and urban and rural planning management has trained a large number of professionals in the fields of resource utilization, urban and rural planning, environmental protection, real estate development, land use and planning during ten years. These professionals provided important support for China's rapid economic development. However, there are some problems, such as vague professional positioning, poor pertinence of curriculum system, lack of practical ability and unclear employment direction of graduates. This puts forward new requirements for professional reform and development under the new situation. So the ministry of education adjusts the major in the new professional catalogue (2012). In the new professional adjustment, the major of resource environment and urban and rural planning management is divided into two undergraduate majors: humanistic geography and urban-rural planning and natural geography and resource environment. Both majors can be awarded with a degree in science or management.

According to the goals and requirements of the ministry of education on human geography and urban-rural planning, Since 2013, universities and colleges have worked out plans for the training of new professionals based on their original resources environment and urban and rural planning management.. Many relevant universities in China have made active explorations and attempts on the construction of humanistic geography and urban and rural planning. The following contents are the research and analysis of the professional construction of human geography and urban-rural planning from two aspects: professional orientation and curriculum system construction. 


\section{Professional Orientation of Human Geography and Urban-Rural Planning}

\section{Policy Orientation of Undergraduate Education In Human Geography And Urban-Rural Planning}

The Higher Education Law of the People's Republic of China stipulates the following standards for undergraduate education: "Students shall be enabled to acquire more systematically the basic theory and basic knowledge, the basic skills, methods and relevant knowledge necessary for their profession. According to the academic background and the teaching research level of universities in China, the undergraduate colleges and universities can be divided into three types: research type, teaching research type and teaching type. Different types of colleges have different training goals and requirements for professionals, and there are also great differences in the orientation of cultural geography and urban and rural planning.

Basis on the ministry of education's undergraduate major catalogue (2012), the human geography and urban-rural planning are under the geographical science category, with a bachelor of science or a bachelor of management degree. The objective of the training is to train high-quality and multi-disciplinary professionals with basic theories, knowledge and skills in the fields of human geography and urban-rural planning management, with innovative spirit and practical skills, trained in rigorous scientific thinking and good professional skills, based on macro-and meso-regional planning and land management, engaged in research, teaching, development or application of urban and rural construction and regional economic development planning ${ }^{[1]}$. According to the requirement of this professional catalogue, the orientation of human geography and urban-rural planning should emphasize the urban and rural planning in the background of geography, and should be different from the urban - rural planning under architecture.

\section{Professional Orientation Research}

For the research on the orientation of human geography and urban-rural planning, many scholars have carried on the exploration from the level of the national undergraduate education, professional connotation and student employment and so on. Wang Jichang believes that the orientation of human geography and urban-rural planning should be considered from the perspective of the characteristics of the subject and the direction of student employment, and the orientation of this major should be urban -rural planning and tourism planning under the background of geography. Because the major of human geography and urban-rural planning belongs to the one level discipline of geography, the major still should insist geography basic discipline position and characteristics, it should emphasize the combination of humane geography and urban- rural planning ${ }^{[2]}$.

$\mathrm{Wu}$ Xiao-min analyzed the different gradations of the National undergraduate training, professional connotations and needs of Yunnan local economic and social development, Summarized the three stages of training experience of this major in the Yunnan agricultural university, and put forward the professional orientation of local colleges and universities should be career oriented[3].Based on the new situation of urban and rural transformation in China and the characteristics of the curriculum system and training requirements, Zhao Rongqin proposed that the human geography and the urban-rural planning major can focus on the two major professional directions of the humanity geography and the sustainable development of the region, and urban-rural planning technology and application. The major can be constructed from the perspective of theory and application [4]. Yang Xiaoxia put forward that the professional orientation of human geography and urban-rural planning of Southwest university should be based on multi-disciplinary integration and " $1+2+1$ " model of talent training, guided by market demand, according to the basic idea of strengthening the foundation, broadening the professional caliber, strengthening ability training, emphasizing quality education and enhancing adaptability. The professional orientation will focus on remote sensing and geographic information science, natural geography, human geography, resources and environment, and urban and rural planning, and serve the development of the western region and the local economy [5]. Liu Fugang proposes that the orientation of human geography and urban-rural planning should be based on the development of higher education and the cultivation of talents, and relied on the basic advantages and characteristics of geosciences in 
colleges and universities to serve regional economic development. The innovative applied talents of "thick moral qualities and outstanding talents" should be cultivated [6].

Based on the characteristics of the Geology and minerals class of colleges and universities, Zhang Qianfeng gives the position of human geography and urban-rural planning as follows: taking the resources, environmental problems and human concerns in the process of urbanization as the opportunity to serve the development of local , and the coordinated development of relationship on human and physical space, students should master the basic theories, knowledge and skills of human geography and urban -rural planning. The students would be able to apply geographic information science and technology to carry out urban and rural planning and to realize Informatization in the planning and management work [7]. Zheng Yanxia taking Heze college as an example, studied the professional orientation of human geography and urban-rural planning undergraduate major, and pointed out that Heze college, as a local comprehensive university that has just been consolidated and upgraded, has the task of cultivating applied and complex talents for local economic and social development. The major should Focus on the development of students 'hands-on skills and the ability to use knowledge to solve problems, and realize the change from training urban and rural managerial talents to training urban and rural planning and design talents to meet the demand of urban and rural planning and development[ 8] .

\section{Construction of Professional Curriculum System}

\section{Setting Principles for Curriculum Systems}

$\mathrm{Xu}$ Shuhui proposed three basic principles of the curriculum system of human geography and urban-rural planning: (1) The principle of solid theoretical foundation. The curriculum system both should be fully embodies the geography theory such as remote sensing and GIS technology, and reflect some basic principles and methods of similar disciplines such as urban planning, environmental science and management science, advanced mathematics, computer and other basic knowledge and application skills, etc. (2) The principle of broadening practice. The practical curriculum system of human geography and urban -rural planning should be set up for in-class practical links, on-campus practical training platforms and out of school practical practice bases, according to the requirement of the basic skills and professional practice and innovation skills. (3) The principle of highlighting local characteristics. Human geography and urban-rural planning major should adapt to the local economic development and social demand, make full use of the advantages of the relevant disciplines and the teaching and scientific research conditions of the universities, and select the cultivation direction that highlights the local characteristics ${ }^{[9]}$.

Zhou Xiaoyan proposed the principle of flexible curriculum for human geography and urban -rural planning majors. The professional direction course setting should not mechanically compress the class hours and proportion of professional course, should give full consideration to shunt cultivation, the development trend of the school type, and professional characteristics of running school. The professional curriculum system should reflect the flexibility and diversity. The content of professional courses should be able to reflect the reality of scientific and technological progress and social development in a dynamic and open manner, and include the latest achievements of the subject development ${ }^{[10]}$.

\section{Setting of Professional Curriculum System}

According to the website information and relevant literatures of universities in China, the curriculum system of human geography and urban-rural planning is mainly composed of the following categories: (1) geography courses: physical geography, human geography, economic geography, natural resources and urban geography; (2) environmental courses: environmental science, urban ecology, etc.; (3) urban - rural planning courses: regional analysis and planning, principles of urban planning, residential planning, urban general planning, land planning and management; (4) planning technology and geographic information technology courses: geographic information system, remote sensing introduction, surveying, cartography, computer aided planning 
and design, urban and rural planning information technology, etc.

The first two of them focus on the theory and the latter two on the technical application. Taking into account the difference of between the key institutions and local universities in china, we selected colleges and universities with representative human and geography and urban-rural planning to analyze the goal of training professional talents and the main courses (see Table 1).

Table.1 Construction of human geography and urban- rural planning major in some universities

\begin{tabular}{|c|c|c|}
\hline $\begin{array}{l}\text { School } \\
\text { name }\end{array}$ & Professional training objectives & Major courses \\
\hline $\begin{array}{c}\text { Beijing } \\
\text { normal } \\
\text { university }\end{array}$ & $\begin{array}{l}\text { Students mainly study the relevant } \\
\text { disciplines of human geography and } \\
\text { urban-rural planning, such as } \\
\text { mathematics, physics and computer } \\
\text { science, etc, and master professional } \\
\text { basic principles, knowledge and skills. } \\
\text { Basic skills and methods of remote } \\
\text { sensing and GIS should be mastered. The } \\
\text { relevant policies and regulations of } \\
\text { China's resource environment protection } \\
\text { and sustainable development strategy, and } \\
\text { professional frontier issues, should be } \\
\text { studied. Students should master the basic } \\
\text { methods of data query, document } \\
\text { retrieval and modern information } \\
\text { technology. }\end{array}$ & $\begin{array}{l}\text { economic geography, urban geography, } \\
\text { population geography, transportation, } \\
\text { geography, urban ecology, real estate } \\
\text { appraisal and development, natural } \\
\text { resources and environmental law, } \\
\text { environmental impact assessment, land } \\
\text { evaluation and land management, } \\
\text { environmental science, geology and } \\
\text { geomorphology, urban planning } \\
\text { principles, regional analysis and } \\
\text { planning, land use planning, tourism } \\
\text { geography and tourism planning, } \\
\text { geographic information systems, } \\
\text { surveying and mapping, remote } \\
\text { sensing, etc. }\end{array}$ \\
\hline $\begin{array}{l}\text { Wuhan } \\
\text { university }\end{array}$ & $\begin{array}{l}\text { Students mainly study the basic theories } \\
\text { and knowledge of geography, urban } \\
\text { planning, management science and } \\
\text { economics; master the basic principles } \\
\text { and methods of human and urban-rural } \\
\text { planning. The higher scientific literacy } \\
\text { and practical skills should be mastered. } \\
\text { The senior professional talents will be } \\
\text { cultured in urban and regional planning } \\
\text { and design, urban and rural construction, } \\
\text { urban management and mapping, remote } \\
\text { sensing and GIS application. }\end{array}$ & $\begin{array}{l}\text { human geography, natural geography, } \\
\text { introduction to geographical science, } \\
\text { economic geography, regional } \\
\text { planning, urban geography, landscape } \\
\text { ecology, urban planning principle, } \\
\text { regional analysis and planning, } \\
\text { metrology, village planning, land } \\
\text { economics, geographic landscape } \\
\text { model and simulation, environmental } \\
\text { planning and management, remote } \\
\text { sensing technology and application, } \\
\text { digital mapping, geographic } \\
\text { information system application, etc. }\end{array}$ \\
\hline
\end{tabular}


Table 1, cont.

\begin{tabular}{|c|c|c|}
\hline $\begin{array}{c}\text { Sun } \\
\text { yat-sen } \\
\text { university }\end{array}$ & $\begin{array}{l}\text { We should train students to have a solid } \\
\text { foundation of natural science, a better } \\
\text { foundation of humanities and social } \\
\text { science, a strong comprehensive ability of } \\
\text { foreign languages and computer skills. } \\
\text { Master the basic theory and method of } \\
\text { geography. Students should master the } \\
\text { basic knowledge of humanities } \\
\text { geography, economic geography and } \\
\text { resource environment, urban-rural } \\
\text { planning management. Methods of } \\
\text { remote sensing, GIS, computer and } \\
\text { mapping should be also mastered. } \\
\text { Students have the ability of apply their } \\
\text { own professional knowledge to urban and } \\
\text { regional planning, preliminary urban and } \\
\text { regional management, and preliminary } \\
\text { academic research and communication. }\end{array}$ & $\begin{array}{l}\text { human geography, urban geography, } \\
\text { economic geography, tourism } \\
\text { geography, industry geography, traffic } \\
\text { geography, population geography, } \\
\text { society geography, politics geography, } \\
\text { regional analysis and planning, urban } \\
\text { planning principle, urban overall } \\
\text { planning, detailed planning principles, } \\
\text { tourism planning, social investigation } \\
\text { and study method. }\end{array}$ \\
\hline $\begin{array}{l}\text { Southwest } \\
\text { university }\end{array}$ & $\begin{array}{l}\text { We should Cultivate Students strong } \\
\text { social responsibility, profound cultural } \\
\text { background, broad international vision, } \\
\text { with the basic theories and skills in } \\
\text { humanities and urban and rural planning. } \\
\text { Students are trained in rigorous scientific } \\
\text { thinking and good professional skills. We } \\
\text { will focus on regional planning and land } \\
\text { management, and train multi-disciplinary } \\
\text { professionals capable of undertaking } \\
\text { urban and rural construction and regional } \\
\text { economic development planning, } \\
\text { environmental protection and scientific } \\
\text { research. }\end{array}$ & $\begin{array}{l}\text { cartography, nature geography, human } \\
\text { geography, geographic information } \\
\text { system, remote sensing, economics, } \\
\text { economic geography, planning and } \\
\text { mapping, regional planning, urban and } \\
\text { rural planning principles, land } \\
\text { resources, environmental science } \\
\text { introduction, etc. }\end{array}$ \\
\hline
\end{tabular}

\section{Conclusion}

In recent years, many scholars have made a lot of work in human geography and urban -rural planning professional construction. However, there are still some problems, such as unclear positioning and different colleges and universities have different courses, the professional orientation and the curriculum system are not mature and so on. The professional construction has a long way to go. At present, China is in the critical period of rapid urbanization and urban and rural transformation development. There are a series of problems in regional economic development, such as resource and environment problems, regional development incoordination, regional economic and social dual structure problems, etc. The solution of these problems urgently needs the professional talents of human geography and urban-rural planning. Therefore, the professional college and teaching staff should be guided by the actual needs of the country and society, and adapt to the requirements of talent training in the new period, so that realizing the connection with the social economy development to the professional talents urgently need. Under the premise of clarifying the direction of professional development, we should improve the curriculum system, consolidate the professional features of different institutions, strengthen the cultivation of practical teaching and innovative ability, and train excellent urban and rural planning talents with geographical backgrounds that are really suitable for the development of the new period. 


\section{Acknowledgement}

This research was supported by the "12th Five-Year" planning of Education Science of Shanxi (GH-15022) and the Teaching Reform Projects of Shanxi University of Finance and Economics(2016111).

\section{References}

[1] Department of higher education of the ministry of education of the People's Republic of China, catalogue and introduction of undergraduate studies in general higher education institutions, Higher Education Press,Beijing,2012, pp. 137-138.

[2] Wang Jichang, Qu Kangqing. Thoughts on the Construction of Humanities Geography and Urban and Rural Planning Under the Background of Geography, Journal of Higher Education. 18 (2015) 204-207.

[3] Wu Xiaomin, Dong ping, Lu Xiang etc. Discussion on the Specialty Orientation of Human Geography and Urban and Rural Planning for the Local University, Journal of Yunnan Agricultural University. 1(2015) 51-55.

[4] Zhao Rongqin, Ding MingLei, Xu Chenguang etc. An Analysis on the Development Direction and Position of Human Geography and Urban-rural Planning Specialty based on the Background of Specialty Renaming, Higher Education of Science. 5(2014) 75-78.

[5] Yang Xiaoxia, Yang Qingyuan, Li Qiu. On Talent Training Mode Reform of Specialty of Human Geography and Urban -Rural Planning-a Case Study of Southwest University, Journal of Southwest China Normal University (Natural Science Edition). 4(2016) 211-215.

[6] Liu Fugang. Thinking on the Construction of Human Geography and Urban and Rural Planning , Experimental Science and Technology. 6(2014)165-167.

[7] Zhang Xifeng, Xue Lifang, Ma Xiaofan. The Construction and Practice on Human Geography and Urban-rural Planning Major, Higher Education of Science. 1(2016)96-101.

[8] Zheng Yanxia. Talent Training Mode of Human Geography and Urban Planning Specialty In Local Colleges and Universities: Taking Heze University as an Example, Journal of Architectural Education In Institutions of Higher Learning. 5(2015) 32-36.

[9] Xu Shu-hui, Zuo Panshi, Li Hangfei. Human Geography and Urban-Rural Planning System Construction Exploration , Geography Education. 5 (2013) 59-60.

[10] Zhou Xiaoyan, Li Qiuli, Dai Zhanyong etc. A Study on the Specialty Orientation and the Construction of Curriculum System for Human Geography \& Urban -Rural Planning Major in Chinese Universities , Higher Education of Sciences. 1(2017) 82-87. 